\title{
Spectrum Analysis of Cases of Japanese Encephalitis in Jharkhand, India
}

\author{
Dr Amar Verma ${ }^{1}$, Dr Zeeshan Ahmed ${ }^{2}$, Dr Shashank Shekhar ${ }^{3}$, \\ Dr Monazeer Ahsan ${ }^{4}$ \\ ${ }^{I}$ Deputy Director (Genetic Diseases \& Research) and Associate Professor, Department of Pediatrics \& \\ Neonatology, RIMS, Ranchi \\ ${ }^{2}$ Junior Resident, Department of Pediatrics, RIMS, Ranchi \\ ${ }^{3}$ Junior Resident, Department of Pediatrics, RIMS, Ranchi \\ ${ }^{4}$ Junior Resident, Department of Pediatrics, RIMS, Ranchi
}

\begin{abstract}
Japanese Encephalitis is increasingly becoming a major cause of viral encephalitis in many countries of Asia including India. Though initially thought to be sporadic, cases are found all year around in Jharkhand. There is no specific drug against the virus as of yet hence, without high level supportive care the mortality can be as high as $42 \%$ especially in children and elderly.This study encompasses 14 proven cases of Japanese Encephalitis admittedfrom September 2015 to October 2016 in Unit-II of Department of Paediatrics, RIMS, Ranchi. This is an observational study and throws light upon the presenting complains, natural history, duration of stay, clinical outcome and presence of sequel in cases of JE in and around the state of Jharkhand, India.The results show that the cases were mostly clustered during the months of August and September. The mean age of presentation is 9.86 years. Most common presenting complaints were fever (100\%) and abnormal body movement $(85.7 \%)$. The mean duration of hospital stay was 16.14 days. With provision of high level tertiary care facility, only 1 deathoccurred(7.1\%) and 4 patients(28.5\%) did not suffer any sequel. Amongst those who had residual sequel the most common were speech disturbances(50\%) and tremors(42.8\%).
\end{abstract}

Keywords: Acute Encephalitic Syndrome, Japanese Encephalitis, spectrum analysis

\section{Introduction}

Japanese Encephalitis virus is a member of group B Arbovirus(Flavivirus) related to Dengue, Yellow Fever and West Nile viruses. ${ }^{2,7}$ The chief vector of the virus is Culextritaennorhynchus. In India members of the closely related Culexvishnui group are the chief vectors. ${ }^{1}$ The virus exists in a transmission cycle between mosquitoes, pigs and/or water birds (enzootic cycle). ${ }^{2}$ Pigs are the amplifying hosts while humans once infected cannot infect feeding mosquitoes. ${ }^{2}$ The disease is mostly found in rural and peri-urban settings where humans live in close proximity with vertebratehosts. ${ }^{2}$ In most temperate regions of Asia, Japanese Encephalitis is transmitted mainly during warm season but in the tropics and subtropics, transmission occurs all year round but mostly during rainy season and pre-harvest period in rice-cultivating regions. ${ }^{2}$

The case: infection ratio has been variably estimated at $1: 25$ to $1: 1000 .{ }^{1}$ Most infections are asymptomatic or non-specific with encephalitis estimated to occur in only 1 in 300 infections. ${ }^{3}$ The presenting features are mostly abrupt onset of fever, headache, respiratory symptoms, abdominal pain, vomiting, altered mental states and convulsions especially in children. ${ }^{3}$ To confirm Japanese Encephalitis virus infection and to rule out other causes of encephalitis requires a laboratory testing of serum or preferentially cerebrospinal fluid. ${ }^{2}$

Treatment is mostly supportive including control of seizures and access to high level support is important in survival of severe cases. ${ }^{1}$ Case fatalityrates for Japanese Encephalitis are $24-42 \%$ and are highest is in children 5-9 years of age or adults $>65$ years age. ${ }^{1}$

If the active stage is survived, $25-50 \%$ will have neurological sequelae mostly paralysis, ataxia, Parkinsonism, mental deterioration, psychiatric disorders and speech difficulties. ${ }^{3}$

\section{Materials and Methods}

All the patients who were suspected to have Acute Encephalitic Syndrome(AES) were investigated forIgM antibodies for JE in their CSF. Under full aseptic and antiseptic conditions, lumbar puncture was done and $0.5 \mathrm{ml}$ of CSF was collected and sent for serology testing for JE.

Those patients who had positive serology against JE were included in the study. The present study was done to know the clinical course, natural history, immediate outcome and sequel of Japanese Encephalitis patients admitted in the Unit-II of Department of Paediatrics, RIMS, Ranchi. These cases will then be followed up at 6 months for any residual sequelae. 
This is a 1year prospective observational study in which 14 cases of Japanese Encephalitis admitted during September 2015 to October 2016 in the Unit-II of Department of Paediatrics, RIMS, Ranchiwere included.

\section{Inclusion Criteria}

All patients who were clinically suspected \& tested positive in the serological tests of CSF for Japanese Encephalitis were included in the study.

\section{Method of Collection of Data}

At admission parents/guardians were informed about the study and written informed consents were taken. A detailed history was obtained with special focus on any domesticated animals and proximity to rice farms.

All the cases underwent necessary investigations:-

1. Complete blood count

2. Peripheral blood smear examination

3. Blood smear for malarial parasite- thick and thin

4. R/E of cerebrospinal fluid

5. CSF for Japanese Encephalitis virus IgM serology

The next step was to tabulate all the Japanese Encephalitis cases and to compare their presenting complaints, examination details, investigations reports, treatment given, outcome and immediate sequelae.

\section{Results}

All the cases studied throughout the year presented in the month of August and September.Among the 14 patients studied, 9 were males(64.3\%) and 5 were females(35.7\%). The mean age of cases was 9.86 year (boys-9.78years, girls-10 years).[Table-2. Figure-1].The patients presented with varied chief complaints the frequency of which the most common were fever(100\%), abnormal body movement $(85.7 \%)$, altered sensorium(64.3\%), Vomiting $(42.8 \%)$ and headache(28.6\%). Other less common presenting complaints includedpain abdomen(14.2\%), Not passing stools(7.1\%), pain during urination(7.1\%), right sided weakness $(7.1 \%)$, and loss of appetite( $(7.1 \%)$ [Table-3. Figure-2]

The mean duration of hospital stay was 16.14 days(males-15.67 days, females-17 days). 4 of the patients $(28.5 \%)$ did not have any sequelae. Amongst the ones which had sequelae the most common was speech problems(50\%), followed by tremors(42.8\%), dystonia(14.2\%), emotional lability(14.2\%), and right sided weakness(7.1\%).[Table-4, Figure-3]. There occurred only 1 death among the 14 cases(7.1\%).

\section{Conclusion}

Most of the cases presented during the months of August and September which coincides with the rice harvest season of the regional area when there in a sudden surge in the number of infecting mosquitoes of Culex spp. Kakoti et al found out that the most common presenting features of JE in children were fever $(100 \%)$, altered sensorium(83.58\%), seizures(80.08\%), headache(41.79\%) and vomiting $(29.85 \%)$ which are consistent with our results.

The fraction of deaths amongst the cases were higher in other previous studies by Basumatary et al(15.5\%), Baruah HC et al(20.5\%) and Kakoti G et al(14.7\%) as compared to $7.1 \%$ in our study.

Other studies show that the most common sequel of JE were parkinsonian features $(45.45 \%$ by Basumtaray et al, $10 \%$ by Baruah et al) which is consistent with our study where the 2 most common sequel at discharge were speech problems $(50 \%)$ and tremors $(42.8 \%)$. Previous studies and texts suggest that convulsions in Japanese Encephalitis are most common in children and here too we find that the most common presenting complaints were fever and abnormal body movements.

The treatment of JE is mainly supportive and here in the study we provided high quality tertiary care to the patients and the outcome was that only 1 of the patients died and as many as 4 of them did not have any residual sequelae.Amongst the ones which had sequelae of JE infection the most common was speech disturbances and tremors.

\section{References}

[1] Scott B Halstead..Japanese Encephalitis..Kleigman RM,Behrman RE, Stanton BF, Schor NF, Geme III JW, Nelson Textbook of Pediatrics, 20 $0^{\text {th }}$ Edition, Elsevier, 2016: 1627.

[2] Media Centre, Japanese Encephalitis..Factsheet No. 386, December 2015 [http://www.who.int/mediacentre/factsheets/fs386/en/]

[3] Young PR, Lisa F P NG, Hall RA, Smith DW, Johansen CAArbovirusInfections..Farrar J, Hotez PJ, Junghans T, Kang G, Lalloo D, White N..Mansons Tropical Diseases, $23^{\text {rd }}$ Edition, Elsevier, 2014: 129-161

[4] Basumatary LJ, Raja D, Bhuyan D, Das M, Goswami M, Kayal AK, Clinical and radiological spectrum of Japanese Encephalitis, Journal of Neurological Sciences-Elsevier, 2013 Feb 15: 325(1-2), 15-21

[5] Kakoti G, Dutta P, Ram Das B, Borah J, Mahanta J, Clinial profile and outcome of Japanese Encephalitis in children admitted with Acute encephalitic syndrome, BioMed Research International, 2013: 2013, 152656 
[6] Baruah HC, Biswas D, Patgiri D, Mahanta J, Clinical outcome and neurological sequelae in serologically confirmed cases of Japanese Encephalitis patients in Assam, India, Indian Pediatrics, 2002, Dec; 39(12), 1143-8

[7] Chourjit KSH, Gupte S, Pediatric Viral Infections..Gupte S, The Short Textbook of Pediatrics, $11^{\text {th }}$ Edition, Jaypee Brothers Medical Publishers (P) Ltd, 2009: 247-269

Table-1

\begin{tabular}{|c|c|c|c|c|c|c|c|}
\hline $\begin{array}{l}\text { Patient } \\
\text { No }\end{array}$ & Age(years) & Sex & $\begin{array}{l}\text { Date of } \\
\text { Admission }\end{array}$ & $\begin{array}{l}\text { Date of } \\
\text { Discharge/Death }\end{array}$ & $\begin{array}{l}\text { Duration } \\
\text { Stay(Days) }\end{array}$ & Presenting Complains & $\begin{array}{l}\text { Outcome/Sequel } \\
\text { At Discharge }\end{array}$ \\
\hline 1 & 12 & Male & $20 / 09 / 2015$ & $18 / 10 / 2015$ & & $\begin{array}{ll}\text { Fever, abnormal body } & \text { bavements, } \\
\text { Monsorium } & \text { altered } \\
\text { sent }\end{array}$ & $\begin{array}{l}\text { Speech problems, } \\
\text { emotional lability }\end{array}$ \\
\hline 2 & 15 & Male & $23 / 09 / 2015$ & $13 / 10 / 2015$ & 20 & $\begin{array}{l}\text { Fever, abnormal body } \\
\text { movement, altered sensorium }\end{array}$ & $\begin{array}{l}\text { Speech problems, } \\
\text { tremor }\end{array}$ \\
\hline 3 & 5 & Male & $26 / 092015$ & $20 / 10 / 2015$ & 24 & $\begin{array}{l}\text { Fever, abnormal body } \\
\text { movement, altered sensorium }\end{array}$ & $\begin{array}{l}\text { Speech problems, } \\
\text { tremors, dystonia }\end{array}$ \\
\hline 4 & 10 & Female & $16 / 09 / 2015$ & $10 / 10 / 2015$ & 14 & $\begin{array}{l}\text { Headache, abnormal body } \\
\text { movement, altered sensorium }\end{array}$ & No sequelae \\
\hline 5 & 7 & Male & $10 / 09 / 2015$ & $25 / 09 / 2015$ & 15 & $\begin{array}{l}\text { Fever, abnormal body } \\
\text { movement, altered sensorium }\end{array}$ & No sequelae \\
\hline 6 & 8 & Male & $10 / 09 / 2016$ & $20 / 09 / 2016$ & 8 & $\begin{array}{l}\text { Fever, abnormal body } \\
\text { movement, not passing stool }\end{array}$ & $\begin{array}{l}\text { Speech problems, } \\
\text { tremors, dystonia }\end{array}$ \\
\hline 7 & 13 & Male & $27 / 08 / 2016$ & $18 / 09 / 2016$ & 13 & $\begin{array}{l}\text { Pain abdomen, fever, } \\
\text { vomiting, altered sensorium }\end{array}$ & $\begin{array}{l}\text { Speech problems, } \\
\text { tremors }\end{array}$ \\
\hline 8 & 10 & Female & $10 / 09 / 2016$ & $29 / 09 / 2016$ & 19 & $\begin{array}{l}\text { Fever, headache, pain } \\
\text { abdomen, altered sens orium, } \\
\text { vomiting, abnormal body } \\
\text { movement }\end{array}$ & $\begin{array}{l}\text { Speech problems, } \\
\text { emotional lability, } \\
\text { tremors }\end{array}$ \\
\hline 9 & 3 & Male & $11 / 09 / 2016$ & $19 / 09 / 2016$ & 8 & $\begin{array}{l}\text { Fever, pain during urination, } \\
\text { abnormal body movement }\end{array}$ & No sequel \\
\hline 10 & 15 & Male & $18 / 09 / 2016$ & $24 / 09 / 2016$ & 15 & $\begin{array}{l}\text { Fever, vomiting, abnormal } \\
\text { body movement }\end{array}$ & No sequel \\
\hline 11 & 10 & Male & $20 / 09 / 2016$ & $28 / 09 / 2016$ & 10 & $\begin{array}{l}\text { Fever, right sided weakness, } \\
\text { abnormal body movement, } \\
\text { vomiting }\end{array}$ & $\begin{array}{l}\text { Tremors, right } \\
\text { sided weakness }\end{array}$ \\
\hline 12 & 10 & Female & $20 / 10 / 2016$ & $27 / 10 / 2016$ & 10 & $\begin{array}{l}\text { Fever, Abnormal body } \\
\text { movement, headache }\end{array}$ & Death \\
\hline 13 & 14 & Female & $17 / 10 / 2016$ & $7 / 11 / 2016$ & 20 & $\begin{array}{l}\text { Fever, vomiting, loss of } \\
\text { appetite, altered sensorium }\end{array}$ & $\begin{array}{l}\text { Speech problems, } \\
\text { tremors, dystonia }\end{array}$ \\
\hline 14 & 6 & Female & $06 / 10 / 2016$ & $28 / 10 / 2016$ & 22 & $\begin{array}{l}\text { Fever, headache, vomiting, } \\
\text { altered sensorium, abnormal } \\
\text { body movement }\end{array}$ & speech problems \\
\hline $\begin{array}{l}\text { Mean } \\
\text { Value }\end{array}$ & $\begin{array}{l}9.86 \text { years } \\
M=9.78 \mathrm{yrs} \\
\mathrm{F}=10 \mathrm{yrs}\end{array}$ & & & & $\begin{array}{l}16.14 \text { days } \\
M=15.67 \text { days } \\
F=17 \text { days }\end{array}$ & & \\
\hline
\end{tabular}

Table-2

\begin{tabular}{|l|l|l|l|}
\hline SI No & Gender & Frequency(out of 14) & Percentage \\
\hline 1 & Male & 9 & $64.3 \%$ \\
\hline 2 & Female & 5 & $35.7 \%$ \\
\hline
\end{tabular}

Table-3

\begin{tabular}{|l|l|l|l|}
\hline SL NO & Presenting Complaint & Frequency (out of 14) & Percentage \\
\hline 1 & Fever & 14 & $100 \%$ \\
\hline 2 & Abnormal body movement & 12 & $85.7 \%$ \\
\hline 3 & Altered sensorium & 9 & $64.3 \%$ \\
\hline 4 & Vomiting & 6 & $42.8 \%$ \\
\hline 5 & Headache & 4 & $28.6 \%$ \\
\hline 6 & Pain abdomen & 2 & $14.2 \%$ \\
\hline 7 & Not passing stool & 1 & $7.1 \%$ \\
\hline 8 & Pain during micturition & 1 & $7.1 \%$ \\
\hline 9 & Loss of appetite & 1 & $7.1 \%$ \\
\hline 10 & Right sided weakness & 1 & $7.1 \%$ \\
\hline
\end{tabular}

Table-4

\begin{tabular}{|l|l|l|l|}
\hline SL NO & Outcome/Sequel at discharge & Frequency (out of 14) & Percentage \\
\hline 1 & No sequel & 4 & $28.5 \%$ \\
\hline 2 & Speech problems & 7 & $50 \%$ \\
\hline 3 & Emotional lability & 2 & $14.2 \%$ \\
\hline 4 & Tremors & 6 & $42.8 \%$ \\
\hline 5 & Dystonia & 2 & $14.2 \%$ \\
\hline 6 & Right sided weakness & 1 & $7.1 \%$ \\
\hline 7 & Death & 1 & $7.1 \%$ \\
\hline
\end{tabular}


Figure -1

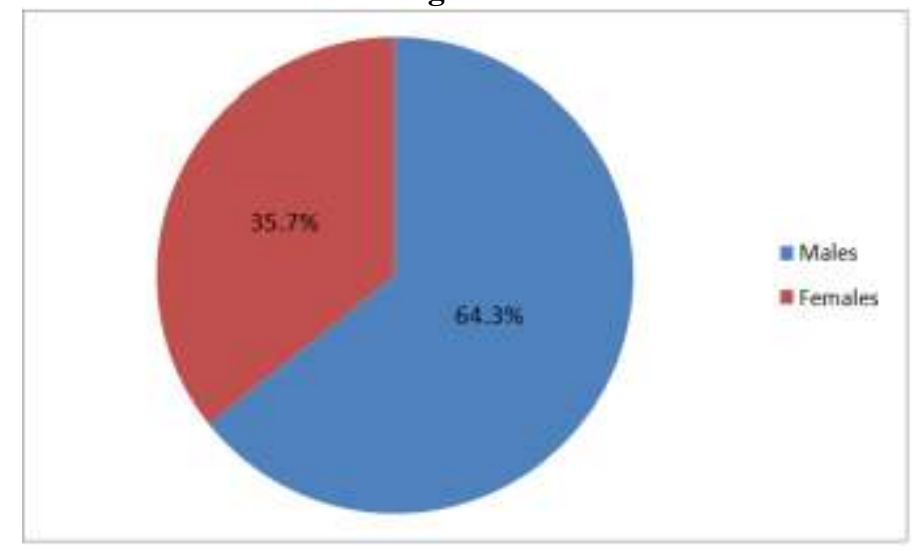

Figure-2

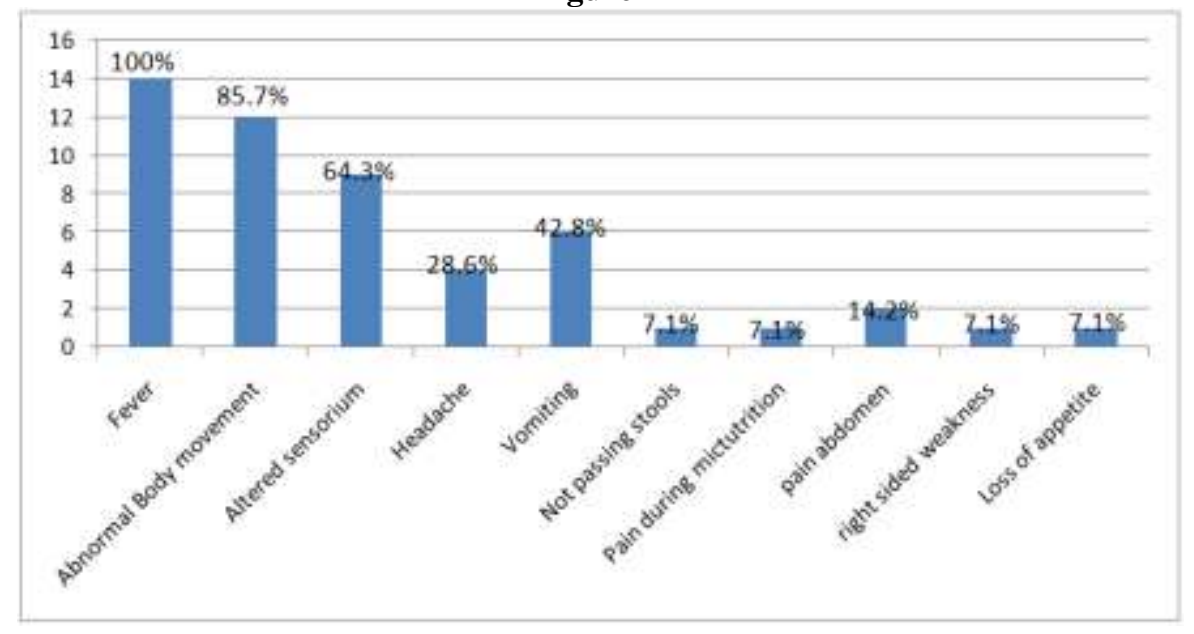

Figure-3

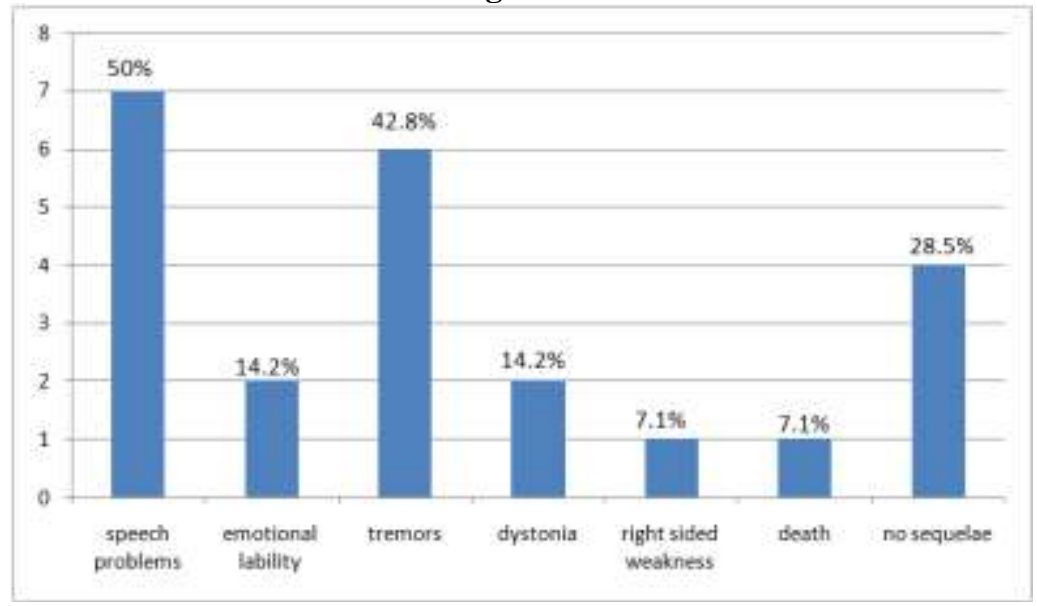

